\title{
Production Systems Influence Source Limitations to Growth in 'Sharpblue' Southern Highbush Blueberry
}

\author{
P.A.W. Swain and R.L. Darnell \\ Horticultural Sciences Department, University of Florida, Gainesville, FL 32611
}

\begin{abstract}
ADDitional INDEX WORDS. carbohydrate, cell division, cell enlargement, flower bud initiation, source-sink, Vaccinium corymbosum interspecific hybrid
\end{abstract}

\begin{abstract}
Sharpblue' southern highbush blueberry (Vaccinium corymbosum L. interspecific hybrid) was grown in either a dormant or nondormant production system to determine the effect of production system on source limitations to fruit and vegetative growth. Source limited stages were evaluated in the two production systems by reducing reproductive sink load during either the fruit cell division or fruit cell enlargement stage. Source limitation during cell division was evaluated by removing $80 \%$ of the flower buds in late fall, since the majority of cell division in blueberry ovaries occurs before bloom. Source limitation during cell enlargement was evaluated by removing $80 \%$ of the fruit after fruit set the following spring. In the dormant production (DP) system, mean fruit dry weight (DW) was greatest in the flower bud removal treatment and least in the control (nonthinned) treatment, suggesting that cell number, rather than size, is more important in determining blueberry fruit weight in the DP system. Fruit in the dormant flower bud removal treatment may have approached maximum cell number and therefore fruit size; this was supported by the observation that significant depletion of root carbohydrate concentration did not occur in this treatment, as it did in the control treatment. Mean fruit DW in the nondormant production (NDP) system was greatest in the fruit removal treatment compared with the other two treatments, suggesting that cell enlargement played a larger role in determining fruit size in this production system. However, the effect of the flower bud removal treatment (and therefore the effect of cell division) on fruit DW in the NDP system was apparently masked by continued flower bud initiation in this system after flower bud removal in late fall. Continued floral initiation was apparently an alternative sink to increasing cell division in previously formed flower buds. In both systems, fruit removal increased vegetative growth compared with the control and flower bud removal treatments. Thus, both systems exhibited source limitations to fruit and vegetative growth, although the timing and extent of the limitation to fruit growth differed between the production systems.
\end{abstract}

Reproductive development in plants is influenced by the total number of reproductive and vegetative sinks and the carbohydrate $\left(\mathrm{CH}_{2} \mathrm{O}\right)$ sources available. Limitations in source supply may reduce both fruit and vegetative sink development. Source limitations during early fruit development may decrease cell division, whereas limitations during later fruit development may decrease cell enlargement, either would decrease fruit size (Stephenson, 1981). High flower bud density in southern highbush blueberry (Vaccinium corymbosum interspecific hybrid) decreased reserve $\mathrm{CH}_{2} \mathrm{O}$ sources, resulting in decreased vegetative growth (Maust et al., 1999). Periods of source limitation to reproductive and vegetative development can be assessed by manipulating the source $\left(\mathrm{CH}_{2} \mathrm{O}\right)$ supply or the sink demand. Removing or shading leaves during reproductive development can decrease the $\mathrm{CH}_{2} \mathrm{O}$ supply to the plant, decreasing fruit yield and/or fruit size (Grappadelli et al., 1994; Ramirez et al., 1988; Roper et al., 1992; Stutte and Martin, 1986). Reducing the reproductive sink load increases the $\mathrm{CH}_{2} \mathrm{O}$ supply to the remaining sinks and can increase mean fruit weight (Birrenkott and Stang, 1990; Gucci and Flore, 1989) and/or vegetative growth (Grossman and DeJong, 1995).

Fruit development in many crops, including blueberry ( $\mathrm{Vac}$ cinium L. sp.), follows a double sigmoidal pattern (Birkhold et al., 1992; Pavel and DeJong, 1993). The initial stage of fruit development is primarily cell division, followed by a stage of embryo development, and finally cell enlargement. Work with peach [Prunus persica (L.) Batsch (Peach Group)] indicates that the first and third growth stages are subject to source limitations, while the second stage is considered to be sink limited (Pavel and DeJong, 1993).

Received for publication 9 July 2001. Accepted for publication 28 Jan. 2002. Florida Agricultural Experiment Station journal series R-08530.
In southern highbush blueberry, source limited stages during reproductive development have not been documented. However, an inverse relationship between blueberry fruit size and number has been identified (Siefker and Hancock, 1986), and the effect of increasing flower bud density on decreasing fruit size and quality (Maust et al., 1999) suggests that source limitations to reproductive development occur in blueberry. Since $80 \%$ of the cells in ripe blueberry fruit are formed before floral budbreak (CanoMedrano and Darnell, 1997), a significant sink demand may occur between flower bud initiation in the fall and floral budbreak in the spring (Darnell and Birkhold, 1996; Maust et al., 1999).

Two blueberry production systems are currently used in Florida, the traditional dormant production (DP) system and the nondormant production (NDP) system. In the DP system, the plants enter endodormancy and chilling is required for budbreak. In the NDP system, plant growth is stimulated by continuous $\mathrm{N}$ applications throughout the year. Plants do not enter endodormancy and a chilling requirement is not needed. Floral and vegetative budbreak occur in the spring when climatic conditions permit. Plants in the NDP system retain their leaves longer into the fall and winter than plants in the DP system, thus the length of the photosynthetic season and $\mathrm{CH}_{2} \mathrm{O}$ production are increased (Swain and Darnell, 2001). The NDP system advances and extends the bloom period and increases fruit number and total fruit fresh weight (FW) compared with the DP system.

The present research examines source limitations to fruit and vegetative growth in 'Sharpblue' southern highbush blueberry and assesses whether the production system influences the timing and/or extent of source limitations. The hypothesis tested was that the lengthened photosynthetic season of the NDP system will increase $\mathrm{CH}_{2} \mathrm{O}$ availability and decrease source limitations to fruit development. The objectives of this study were to 1) determine if source limitations occur during the cell 
division and/or cell enlargement stages of blueberry fruit development, and 2) determine if the NDP system will alleviate these limitations.

\section{Materials and Methods}

VEGETATIVE AND REPRODUCTIVE DEVELOPMENT. In June 1996, 18-month-old rooted stem cuttings of 'Sharpblue' southern highbush blueberry plants were obtained from a commercial nursery. Root balls on each plant were pruned to about a 12-L volume and planted in 22-L containers in a medium of 1 peat : 1 perlite (by volume). Plants were acclimated in a $60 \%$ shade house for 2 weeks, then placed outdoors in full sun for the remainder of the experiment. Broken canes and canes growing parallel to the ground were removed. Between June and Sept. 1996, plants in both systems were fertilized twice weekly with $2.0 \mathrm{~L}$ of Peters $20 \mathrm{~N}-8.8 \mathrm{P}-16 \mathrm{~K}$ water soluble fertilizer solution at $1 \mathrm{~g} \cdot \mathrm{L}^{-1}$ (GraceSierra Hort. Products, Co., Milpitas, Calif.).

In Sept. 1996, canopy volumes of 72 plants were determined by measuring height, widest width, and a third measurement perpendicular to the widest width, and plants were blocked into four replications by estimated canopy volume. Within each replication, plants were paired by size, and one member of each pair was assigned to each production system. Plants were arranged in east-west rows, on 80 to $120 \mathrm{~cm}$ centers. At this time, fertilization was withheld from plants in the DP system, allowing growth to slow and dormancy to occur. The NDP plants continued to be fertilized as described above.

ReProductive TREaTMENTS. To determine when source limitations occur during fruit development in southern highbush blueberry, plant pairs (i.e., one plant from each production system in each replication) were assigned randomly to either a control treatment or one of two reproductive sink removal treatments. The control plants received no reproductive manipulations during the course of the experiment. In the first reproductive sink removal treatment, $80 \%$ of the flower buds on each shoot were removed randomly after it was estimated that flower bud initiation was complete (15 to 31 Dec. 1996), to determine whether a source limitation to fruit development occurred during either the cell division stage or the cell enlargement stage.

In the second reproductive sink removal treatment, $80 \%$ of the fruit were randomly removed from each shoot after fruit set (22 to 23 Feb. 1997 in the NDP system, $\approx 40 \mathrm{~d}$ after bloom; 20 to 25 Mar. 1997 in the DP system, $\approx 50 \mathrm{~d}$ after bloom), to isolate a source limitation during the cell enlargement stage of blueberry fruit development.

Data collection. Before the flower bud removal treatment, flower buds were counted on all plants. Twenty southern highbush blueberry genotypes from the University of Florida blueberry breeding program were placed outside around the experimental plants on 2 Jan. 1997 to promote cross-pollination. In midApril, twice weekly nutrient fertilization was resumed on the DP system plants, as described previously.

Whole plants were harvested at different phenological stages during the course of the experiment. Plant pairs within each replication and from each treatment were assigned randomly for harvesting at one of the following five phenological stages: before flower bud initiation and differentiation (Pre-FBI, control treatment only); after flower bud initiation and differentiation (FBI, control treatment only); $50 \%$ bloom (when $50 \%$ of the flower buds had opened, control and flower bud removal treatments only); $50 \%$ fruit set (when $50 \%$ of the flower buds that opened had set fruit, control and flower bud removal treatments only); and immediately after the final fruit harvest (control, flower bud removal, and fruit removal treatments). Four single plant replications were harvested at each phenological stage representing each production system and treatment combination. In some cases, the calendar dates of the phenological stages, and therefore the whole-plant harvest dates, differed between the production systems (Table 1).

At each whole plant harvest, plants were divided into vegetative and reproductive organs. Fresh weight, dry weight (DW), and number or area, if applicable, were measured for each organ type. Leaf area was measured using a portable leaf area meter (LI-3000; LI-COR, Lincoln, Nebr.). Lengths of all plant canes (main stems arising from the stem-root junction of the plant) and side stems from these canes were measured and recorded as total cane length. Root FW was recorded after roots were washed free of the potting medium. Plant parts were dried at $70^{\circ} \mathrm{C}$ to a constant DW. Dried roots were separated into fibrous $(<1 \mathrm{~mm}$ diameter $)$ and thick ( $>1 \mathrm{~mm}$ diameter) roots and DW for each type was measured.

Fruit began to ripen in mid-March 1997 and ripe fruit was harvested every 3 to $5 \mathrm{~d}$ between $18 \mathrm{Mar}$. and 20 June 1997. Fruit number, FW, and DW were recorded.

Dried canes (not including new spring growth), fibrous roots, and thick roots were ground to pass a 20 mesh $(1.27 \mathrm{~mm}$ mesh) screen. Cane and root soluble $\mathrm{CH}_{2} \mathrm{O}$ were extracted from $50 \mathrm{mg}$ of tissue by shaking for $20 \mathrm{~min}$ in $2 \mathrm{~mL}$ cold $80 \%$ ethanol. Extracts were centrifuged at $1000 g_{\mathrm{n}}$ for $10 \mathrm{~min}$, the supernatant decanted, and the pellet reextracted twice. The supernatants were combined and final volume was measured. Pigment was removed by adding $25 \mathrm{mg}$ activated charcoal, followed by $20 \mathrm{mg}$ polyvinylpolypyrrolidone. Soluble sugars were assayed using the phenolsulfuric acid assay (Chaplin and Kennedy, 1994). An external ${ }^{14} \mathrm{C}$ sucrose standard was used to determine $\mathrm{CH}_{2} \mathrm{O}$ recovery.

Tissue starch content was determined by suspending the extracted pellets in $2 \mathrm{~mL} 0.2 \mathrm{~N} \mathrm{KOH}$ and boiling for $30 \mathrm{~min}$. After boiling, sample $\mathrm{pH}$ was adjusted to 4.5 by adding $1.0 \mathrm{~mL} 1 \mathrm{M}$ acetic acid. Tissue starch was digested by adding $1.0 \mathrm{~mL}$ Rhizopus amyloglucosidase (118 units $/ \mathrm{mL})$ and $1.0 \mathrm{~mL}$ barley malt amylase (4 units $/ \mathrm{mL}$ ) (Sigma Chem. Co., St. Louis), each dissolved in $0.2 \mathrm{~m}$ calcium acetate buffer ( $\mathrm{pH} 4.5$ ) (Scholes et al., 1996). Samples were incubated in a shaking water bath for $24 \mathrm{~h}$ at $37^{\circ} \mathrm{C}$. After incubation, samples were centrifuged as before, the supernatant decanted, and volumes determined. The pellets were redigested as described above. Pigment was removed from supernatants with $25 \mathrm{mg}$ activated charcoal and the glucose liberated from the starch following each digestion was assayed by the phenol-sulfuric acid assay (Chaplin and Kennedy, 1994). A ${ }^{14} \mathrm{C}$ sucrose external standard was used to determine percentage recovery. The assay results from each digestion were summed and analyzed statistically.

The experimental design was a randomized complete block comparing all reproductive treatments between the two production systems at different phenological stages. There were four blocks and each block was considered a replication. Because data sets including all reproductive treatments were available only at the final whole-plant harvest, vegetative comparisons were made only at the final harvest. Carbohydrate data from all harvests and all reproductive treatments were compared together. Data were analyzed by analysis of variance and means separated by Duncan's multiple range test, paired $t$ test, or least square means (SAS Inst. Inc., Cary, N.C.). 
Table 1. Phenological stages and calendar dates for whole-plant harvests of dormant and nondormant system 'Sharpblue' southern highbush blueberry.

\begin{tabular}{|c|c|c|c|}
\hline \multirow[b]{2}{*}{ Phenological stage ${ }^{z}$} & \multirow[b]{2}{*}{ Reproductive treatment } & \multicolumn{2}{|c|}{ Calendar date } \\
\hline & & Dormant & Nondormant \\
\hline Pre-FBI & Control & 3 Oct.1996 & 3 Oct. 1996 \\
\hline FBI & Control & 27 Dec. 1996 & 27 Dec. 1996 \\
\hline Bloom (50\%) & $\begin{array}{l}\text { Control } \\
\text { Flower bud removal }\end{array}$ & 1 Feb. 1997 & 17 Jan. 1997 \\
\hline Fruit set $(50 \%)$ & $\begin{array}{l}\text { Control } \\
\text { Flower bud removal }\end{array}$ & 6 Apr. 1997 & 5 Mar. 1997 \\
\hline Fruit harvest & $\begin{array}{l}\text { Control } \\
\text { Flower bud removal } \\
\text { Fruit removal }\end{array}$ & 10 June 1997 & 11 June 1997 \\
\hline
\end{tabular}

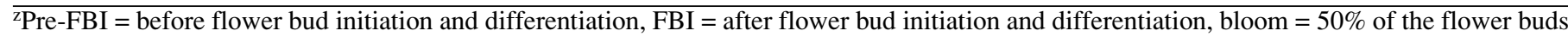
were open, fruit set $=50 \%$ of the flower buds that opened set fruit, and fruit harvest $=$ immediately after final fruit harvest.

\section{Results}

REPRODUCTIVE DEVELOPMENT. No significant interactions between production system and reproductive treatment were observed on final fruit number or total fruit DW at ripening (Table 2). Fruit number was greater in the NDP compared with the DP system plants, and was greatest in the control treatment, followed by flower bud removal, and the fruit removal treatments. Total fruit DW per plant was similar between the systems, and was greater in the control and the flower bud removal treatments compared with the fruit removal treatment.

A significant interaction between production system and reproductive treatment occurred for mean fruit DW (Table 3). Fruit DW was greatest in the DP system flower bud removal treatment, followed by the DP system fruit removal treatment. Mean fruit DW was lowest in the NDP system control treatment.

VegEtative DeVELopMENT. Leaf DW and cane length were greater in the NDP compared with the DP system plants (Table 2). Plants in the fruit removal treatment exhibited greater leaf DW compared with plants in the control and flower bud removal treatments (Table 2). No significant interactions between production system and reproductive treatment for either leaf DW or new cane length were observed; however, there were significant interactions for other vegetative growth responses. New leaf area, cane number, and cane DW were greatest in the NDP system fruit removal plants compared with the other treatments (Table 3 ). Root DW and plant volume were not significantly affected by production system or reproductive treatments, averaging $113 \mathrm{~g}$ and $0.85 \mathrm{~m}^{3}$, respectively (data not presented).

CARbohydrates. In general, there was little effect of system, reproductive treatment, or harvest date on cane or root soluble sugars (Fig. 1). Reproductive treatment had no effect on cane starch concentrations; however, there was a significant system $\times$ harvest interaction for both starch and total $\mathrm{CH}_{2} \mathrm{O}$ (starch + soluble sugar) concentrations ( $P=0.02$ and 0.004 , respectively) (Fig. 1A and B). Cane starch and total $\mathrm{CH}_{2} \mathrm{O}$ concentrations increased between preflower bud initiation and flower bud initiation in both systems, although concentrations were higher in the DP than the NDP system at flower bud initiation and bloom. Starch and total $\mathrm{CH}_{2} \mathrm{O}$ concentrations in canes from both systems decreased by fruit set, and by fruit harvest, concentrations increased in the DP system while remaining constant in the NDP system.

There was a significant system $\times$ treatment $\times$ harvest interaction for root starch and total root $\mathrm{CH}_{2} \mathrm{O}$ concentrations $(P=0.02$ and 0.01 , respectively) (Fig. $1 \mathrm{C}$ and D). The increase in total root

Table 2. Main effects of production system and reproductive treatment on fruit number, fruit dry weight (DW), leaf DW, and cane length in 'Sharpblue' southern highbush blueberry.

\begin{tabular}{|c|c|c|c|c|}
\hline Variable & Fruit/plant ${ }^{\mathrm{z}}$ (no.) & Fruit $\mathrm{DW}^{\mathrm{z}}$ (g/plant) & New leaf $\mathrm{DW}^{\mathrm{y}}(\mathrm{g})$ & New cane length ${ }^{\mathrm{y}}(\mathrm{cm})$ \\
\hline \multicolumn{5}{|l|}{$\overline{\text { System }^{x}(S)}$} \\
\hline DP & $335^{*}$ & 55.0 & $68.1^{*}$ & $800.2^{*}$ \\
\hline NDP & 489 & 61.9 & 111.7 & 1214.5 \\
\hline \multicolumn{5}{|l|}{ Reproductive treatment $(\mathrm{R})$} \\
\hline Control & $546 \mathrm{a}^{\mathrm{w}}$ & $71.7 \mathrm{a}$ & $81.2 \mathrm{~b}$ & 920.8 \\
\hline Flower bud removal $^{\mathrm{v}}$ & $403 \mathrm{~b}$ & $65.8 \mathrm{a}$ & $77.0 \mathrm{~b}$ & 917.1 \\
\hline Fruit removal $^{\mathrm{u}}$ & $171 \mathrm{c}$ & $26.3 \mathrm{~b}$ & $109.6 \mathrm{a}$ & 1184.0 \\
\hline \multicolumn{5}{|l|}{ Significance $(P)$} \\
\hline $\mathrm{S}$ & 0.001 & 0.130 & 0.002 & 0.003 \\
\hline $\mathrm{R}$ & 0.001 & 0.001 & 0.040 & 0.103 \\
\hline $\mathrm{S} \times \mathrm{R}$ & 0.240 & 0.586 & 0.529 & 0.565 \\
\hline
\end{tabular}

${ }^{\mathrm{z}}$ Determined at fruit ripening.

yDetermined after fruit harvest (June 1997).

${ }^{\mathrm{x}} \mathrm{DP}=$ dormant production; NDP $=$ nondormant production.

${ }^{\text {w}}$ Lower case letters indicate mean $(\mathrm{n}=8)$ separation within columns by Duncan's multiple range test, $P \leq 0.05$ for reproductive treatment effects.

vFlower bud removal treatment applied 15 to 31 Dec. 1996.

uFruit removal treatment applied 22 to 23 Feb. 1997 (nondormant system) and 20 to 25 Mar. 1997 (dormant system).

*Indicates means $(\mathrm{n}=12)$ significantly different by paired $t$ test, $P \leq 0.05$ for system effects. 
Table 3. Interactive effects production system and reproductive treatment on mean fruit dry weight (DW), leaf area, cane number, and cane DW in 'Sharpblue' southern highbush blueberry.

\begin{tabular}{|c|c|c|c|c|c|}
\hline Reproductive treatment & System $^{z}$ & Fruit $\mathrm{DW}^{\mathrm{y}}$ (g/fruit) & New leaf $\operatorname{area}^{\mathrm{x}}\left(\mathrm{cm}^{2}\right)$ & New canes ${ }^{\mathrm{x}}$ (no.) & New cane $\mathrm{DW}^{\mathrm{x}}(\mathrm{g})$ \\
\hline \multirow[t]{2}{*}{ Control } & DP & $0.15 \mathrm{c}^{\mathrm{w}}$ & $7390 \mathrm{cb}$ & $81 \mathrm{~b}$ & $19.0 \mathrm{c}$ \\
\hline & NDP & $0.12 \mathrm{~d}$ & $10556 \mathrm{~b}$ & $94 \mathrm{~b}$ & $37.4 \mathrm{~b}$ \\
\hline \multirow[t]{2}{*}{ Flower bud removal $^{\mathrm{v}}$} & $\mathrm{DP}$ & $0.22 \mathrm{a}$ & $6562 \mathrm{c}$ & $79 \mathrm{~b}$ & $18.1 \mathrm{c}$ \\
\hline & NDP & $0.14 \mathrm{~cd}$ & $8958 \mathrm{cb}$ & $109 \mathrm{~b}$ & $34.9 \mathrm{~b}$ \\
\hline \multirow[t]{2}{*}{ Fruit removal $^{u}$} & DP & $0.18 \mathrm{~b}$ & $7582 \mathrm{cb}$ & $88 \mathrm{~b}$ & $22.6 \mathrm{c}$ \\
\hline & NDP & $0.16 \mathrm{c}$ & $14710 \mathrm{a}$ & $177 \mathrm{a}$ & $64.5 \mathrm{a}$ \\
\hline \multicolumn{6}{|l|}{ Significance $(P)$} \\
\hline System $(\mathrm{S})$ & & $<0.001$ & $<0.001$ & 0.009 & $<0.001$ \\
\hline Reproductive treatme & & $<0.001$ & 0.024 & 0.031 & $<0.001$ \\
\hline $\mathrm{S} \times \mathrm{R}$ & & 0.004 & 0.010 & 0.020 & 0.010 \\
\hline
\end{tabular}

${ }^{\mathrm{Z}} \mathrm{DP}=$ dormant production; NDP = nondormant production.

y Determined at fruit ripening.

xDetermined after fruit harvest (June 1997).

wLower case letters indicate mean $(\mathrm{n}=8)$ separation by Duncan's multiple range test, $P \leq 0.05$.

vFlower bud removal treatment applied 15 to 31 Dec. 1996.

uFruit removal treatment applied 22 to 23 Feb. 1997 (nondormant system) and 20 to 25 Mar. 1997 (dormant system).

$\mathrm{CH}_{2} \mathrm{O}$ concentration between preflower bud initiation and flower bud initiation was greater in the DP than the NDP system. Starch concentrations also increased during this time, although these levels were similar between systems.

In the DP system, root starch concentrations decreased between flower bud initiation and bloom in the flower bud removal and control treatment plants. This decrease continued through fruit set, at which time the DP system control plants had significantly lower root starch concentrations than the flower bud removal plants. By fruit harvest, starch concentrations among the three DP system reproductive treatments were similar.

In the NDP system, starch concentrations increased between flower bud initiation and bloom in the flower bud removal treatment plants, but not in the control plants. By fruit set, root starch concentrations decreased in control and flower bud removal treatments. Starch concentrations in the three NDP system reproductive treatments at fruit harvest were not different from each other. Changes in concentration of total root $\mathrm{CH}_{2} \mathrm{Os}$ among reproductive treatments and production systems were similar to changes in starch concentrations.

\section{Discussion}

Blueberry fruit exhibit a double sigmoidal growth curve (Birkhold et al., 1992; Cano-Medrano and Darnell, 1997). The principal cell division stage (Stage I) occurs before floral budbreak, while the principal cell enlargement stage (Stage III) begins between 10 and $25 \mathrm{~d}$ after bloom in rabbiteye blueberry ( $V$. ashei Reade) and continues through fruit ripening (Cano-Medrano and Darnell, 1997). Both these stages may be vulnerable to source limitations, as is the case with peach fruit, which also exhibits double sigmoidal growth (Pavel and DeJong, 1993). Results from the present study show evidence for source limited stages during both Stage I and Stage III of fruit development in 'Sharpblue' southern highbush blueberry. In the DP system, the greater mean fruit DW in the fruit removal treatment compared with the control treatment indicates source limitations during the cell enlargement stage of blueberry fruit development. The increased mean fruit DW in the DP system flower bud removal treatment compared with the other treatments also indicates source limitation to fruit development, which could occur in the cell division and/or cell enlargement stages. However, the greater mean fruit DW coupled with the greater fruit number in the flower bud removal treatment compared with the fruit removal treatment suggests the major source limitation occurred during the cell division stage of fruit development. This suggests that cell number, not cell size, may be the primary determinant of final fruit size in blueberry, as it is in peach (Scorza et al., 1991), strawberry (Fragaria ×ananassa Duch.) (Cheng and Breen, 1992) and apple [Malus sylvestris (L.). Mill. var domestica (Borkh.) Mansf.] (Westwood et al., 1967).

Fruit in the DP system flower bud removal treatment may have approached the maximum potential cell number and therefore the maximum potential fruit size, due to the decreased reproductive sink number during the cell division stage of fruit development. This probably increased source availability to the remaining fruit, possibly to the point where source availability became nonlimiting (Grossman and DeJong, 1995). Although cane and root $\mathrm{CH}_{2} \mathrm{O}$ concentrations were similar between treatments at bloom, control (nonthinned) plants exhibited a marked decrease in root $\mathrm{CH}_{2} \mathrm{O}$ concentrations between bloom and fruit set compared with the flower bud removal plants. This suggests that there was sufficient $\mathrm{CH}_{2} \mathrm{O}$ available to support maximum fruit development in the DP system flower bud removal treatment, since significant depletion of root reserves did not occur. Additionally, there were no compensatory changes in leaf, cane, or root DW in either reproductive treatment between bloom and fruit set that might mask changes in $\mathrm{CH}_{2} \mathrm{O}$ reserves.

In the DP system control and fruit removal treatments, fruit cell number is assumed to be comparable because the mean fruit number (flower bud number) on each plant was similar during the cell division stage. Source allocation to fruit during cell division in these two treatments was probably similar and may have been limiting compared with source allocation to fruit in the flower bud removal treatment. Thus, maximum potential cell number and fruit size was apparently not attained in these two treatments. Studies in peach show that source limitations early in fruit development (i.e., during cell division) result in a permanent loss in growth potential, compared with fruit grown under nonlimited conditions during that same period (Grossman and DeJong, 1995). Although fruit in both the control and fruit removal treatments in the present study may have been source limited during the cell division stage of growth, subsequent fruit thinning apparently ameliorated the source limitation occurring during cell enlargement. Thus, fruit from the fruit removal treatment was 


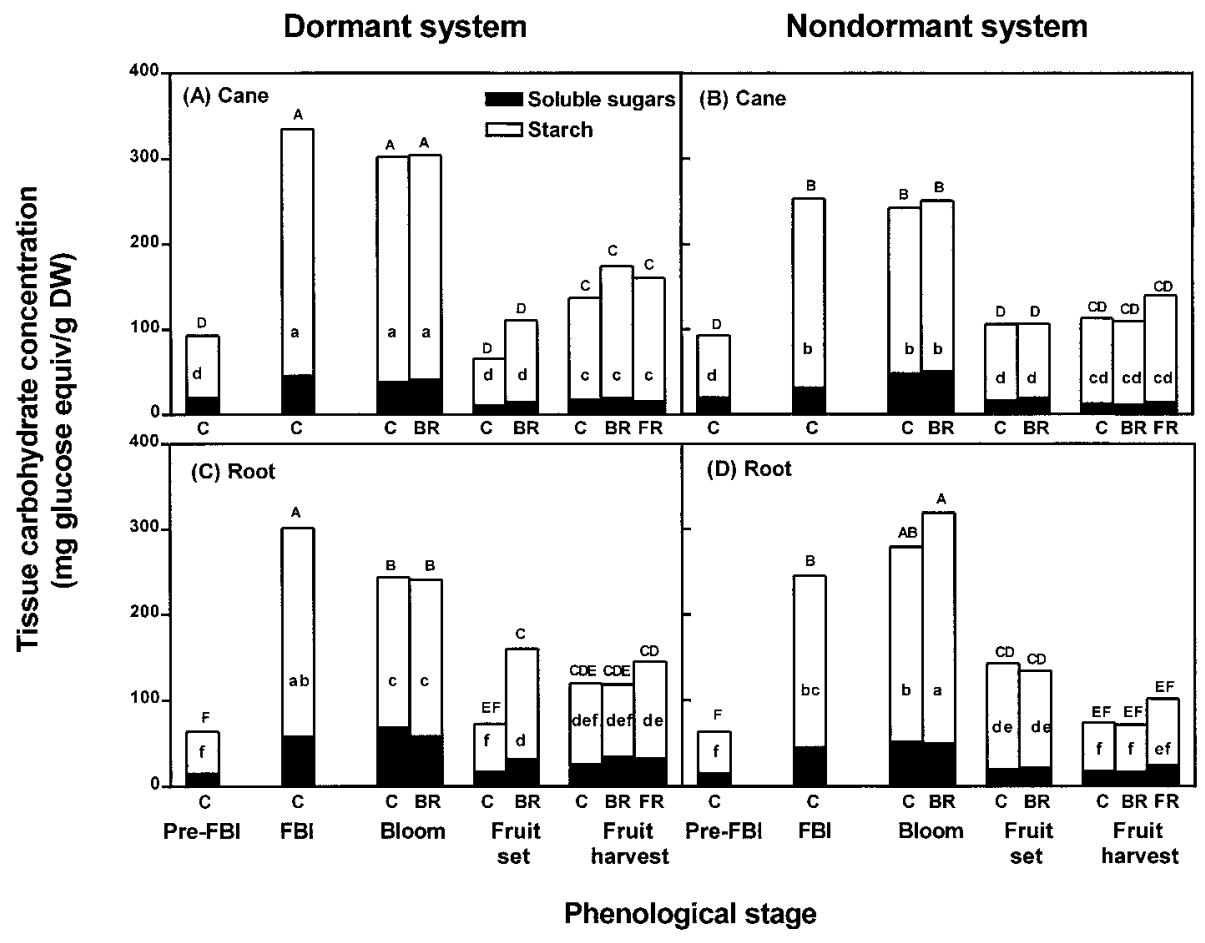

systems, the relative decrease was less in the NDP system (a 20\% decrease) than in the DP system (a 35\% decrease) due to continued flower bud initiation. The $20 \%$ decrease in fruit number in the NDP system flower bud removal treatment was apparently not sufficient to ameliorate sink competition during either of the source limited stages of fruit development, since fruit size was similar in the flower bud removal and control treatments. Although continued flower bud initiation and the resultant increased flower bud number also occurred in the NDP system fruit removal treatment, thinning apparently decreased fruit number sufficiently to ameliorate the source limitation during cell enlargement, resulting in increased fruit size in the fruit removal compared with the control treatment. Similarly, fruit thinning at fruit set increases fruit size in many crops (Pavel and DeJong, 1993; Weinberger, 1941; West-wood et al., 1967), presumably by increasing the $\mathrm{CH}_{2} \mathrm{O}$ supply to remaining fruit (Grossman and DeJong, 1995; Ingles et al., 1995; Pavel and DeJong, 1993; Weinberger, 1941).

Fig. 1. 'Sharpblue' (A and $\mathbf{B})$ cane and $(\mathbf{C}$ and $\mathbf{D})$ root carbohydrate concentrations in dormant and nondormant system plants at different phenological stages and reproductive sink loads. $\mathrm{C}=$ control (nonthinned), $\mathrm{BR}=$ flower bud removal, $\mathrm{FR}=$ fruit removal, Pre-FBI $=$ before flower bud initiation and differentiation, $\mathrm{FBI}=$ after flower bud initiation and differentiation, Bloom $=50 \%$ of the flower buds were open, Fruit set $=$ $50 \%$ of the flower buds that opened set fruit, and Fruit harvest $=$ immediately after final fruit harvest. Mean separation among system, reproductive treatment, and phenological stage by Duncan's multiple range test $(P \leq 0.05)$ for starch (lower case letters) and total $\mathrm{CH}_{2} \mathrm{O}$ (upper case letters) concentrations.

larger compared with fruit from the control.

Source limitations to blueberry fruit development were also evident in the NDP system. The greater mean DW in the fruit removal treatment compared with the control treatment indicates greater source allocation to fruit in the fruit removal treatment during cell enlargement. Since there was no difference in root or cane $\mathrm{CH}_{2} \mathrm{O}$ concentrations among treatments during this time, the fruit DW increase in the fruit removal treatment must have been due to $\mathrm{CH}_{2} \mathrm{O}$ derived from current photosynthesis. The increased leaf area of the fruit removal plants compared with the other treatments probably resulted in increased photosynthesis, which may have increased $\mathrm{CH}_{2} \mathrm{O}$ available for fruit growth. The similarity in fruit DW between the flower bud removal and the control treatments may be due to the continued flower bud initiation throughout the fall and winter in the NDP system plants. Blueberries are short-day plants with respect to flower bud initiation (Darnell, 1991; Hall et al., 1963; Hall and Ludwig, 1961). Increased leaf retention in the fall and winter, as occurs in the NDP compared with the DP system, allows continued perception of the short photoperiod and therefore, continued flower bud initiation in the NDP system plants (Reeder et al., 1998; Swain and Darnell, 2001). Previous work found that flower bud number was greater in NDP compared with DP system plants (Swain and Darnell, 2001). Thus, although the flower bud removal treatment decreased final fruit number compared with the control in both
The increase in vegetative growth in response to the fruit removal treatment indicates a source limitation to vegetative development during the cell enlargement stage of fruit development. This response is similar to responses observed when other fruit crops are thinned (Grossman and DeJong, 1995; Hurd et al., 1979; Pavel and DeJong, 1993; Schaffer et al., 1986; Schechter et al., 1994a, 1994b) and reflects the potential of vegetative sinks to compete for $\mathrm{CH}_{2} \mathrm{O}$ during that time. The flower bud removal treatment had little, if any, effect on stimulating vegetative growth. This was probably due to the general inhibition of vegetative growth in blueberry under the short photoperiod in fall and winter (Aalders and Hall, 1964; Hall and Ludwig, 1961; Hall et al., 1963).

Similar $\mathrm{CH}_{2} \mathrm{O}$ patterns and reproductive responses to what are reported here have been observed in peach and apple trees that received fall $\mathrm{N}$ applications compared with plants not receiving fall N (Taylor and van den Ende, 1970; Terblanche et al., 1979). In those studies, fall $\mathrm{N}$ applications delayed leaf senescence; thereby lengthening the photosynthetic season. Our results indicate that although the lengthened photosynthetic season of NDP system plants increased $\mathrm{CH}_{2} \mathrm{O}$ availability, the additional $\mathrm{CH}_{2} \mathrm{O}$ may have been used for new flower bud initiation rather than increasing cell division and therefore fruit size in previously formed flower buds. Thus, the NDP system aggravated the source limitations to cell division and enlargement in 'Sharpblue' southern highbush blueberry by increasing the fruit number compared with plants in the DP system.

\section{Literature Cited}

Aalders, L.E. and I.V. Hall. 1964. A comparison of flower-bud development in the lowbush blueberry, Vaccinium angustifolium Ait. under greenhouse and field conditions. Proc. Amer. Soc. Hort. Sci. 85:281-284. Birkhold, K.T., K.E. Koch, and R.L Darnell. 1992. Carbon and nitrogen economy of developing rabbiteye blueberry fruit. J. Amer. Soc. Hort. Sci. 117:139-145.

Birrenkott, B.A. and E.J. Stang. 1990. Selective flower removal in- 
creases cranberry fruit set. HortScience 25:1226-1228.

Cano-Medrano, R. and R.L. Darnell. 1997. Cell number and cell size in parthenocarpic vs. pollinated blueberry (Vaccinium ashei) fruits. Ann. Bot. 80:419-425.

Chaplin, M.F. and J.F. Kennedy. 1994. Carbohydrate analysis: A practical approach. $2^{\text {nd }}$ ed. IRL Press at Oxford Univ. Press, Oxford, United Kingdom.

Cheng, G. and P.J. Breen. 1992. Cell count and size in relation to fruit size among strawberry cultivars. J. Amer. Soc. Hort. Sci. 117:946-950.

Darnell, R.L. 1991. Photoperiod, carbon partitioning, and reproductive development in rabbiteye blueberry. J. Amer. Soc. Hort. Sci. 116:856860.

Darnell, R.L. and K.T. Birkhold. 1996. Carbohydrate contribution to fruit development in two phenologically distinct rabbiteye blueberry cultivars. J. Amer. Soc. Hort. Sci 121:1132-1136.

Grappadelli, L.C., A.N. Lakso, and J.A. Flore. 1994. Early season patterns of carbohydrate partitioning in exposed and shaded apple branches. J. Amer. Soc. Hort. Sci. 119:596-603.

Grossman, Y. and T. DeJong. 1995. Maximum fruit growth potential following resource limitation during peach growth. Ann. Bot. 75:561567.

Gucci, R. and J.A. Flore. 1989. The effects of fruiting or fruit removal on leaf photosynthesis and dry matter distribution of tomato. Adv. Hort. Sci. 3:120-125.

Hall, I.V., D.L. Craig, and L.E. Aalders. 1963. The effect of photoperiod on the growth and flowering of highbush blueberry. Proc. Amer. Soc. Hort. Sci. 82:260-263.

Hall, I.V. and R.A. Ludwig. 1961. The effects of photoperiod, temperature, and light intensity on the growth of the lowbush blueberry (Vaccinium angustifolium Ait.). Can. J. Bot. 39:1733-1739.

Hurd, R.G., A.P. Gay, and A.C. Mountfield. 1979. The effect of partial flower removal on the relation between root, shoot, and fruit growth in the indeterminate tomato. Ann. Bot. 93:77-89.

Ingles, P., G. Barbera, T. La Mantia, and S. Portolano. 1995. Crop production, growth, and ultimate size of cactus pear fruit following fruit thinning. HortScience 30:227-230.

Maust, B.E., J.G. Williamson, and R.L. Darnell. 1999. Flower bud density affects vegetative and fruit development in field-grown southern highbush blueberry. HortScience 34:607-610.

Pavel, E.W. and T.M. DeJong. 1993. Source- and sink-limited growth periods of developing peach fruits indicated by relative growth rate analysis. J. Amer. Soc. Hort. Sci. 118:820-824.

Ramirez, D.R., T.C. Wehner, and C.H. Miller. 1988. Source limitation by defoliation and its effect on dry matter production and yield of cucumber. HortScience 23:704-706.
Reeder, R.K., T.A. Obreza, and R.L. Darnell. 1998. Establishment of a nondormant blueberry (Vaccinium corymbosum hybrid) production system in a warm winter climate. J. Hort. Sci. 73: 655-663.

Roper, T.J., E.J. Stang, and G.M. Hawker. 1992. Early season leaf removal reduces fruit set and size in cranberry. HortScience 27:75.

Schaffer, B., J.A. Barden, and J.M. Williams. 1986. Whole plant photosynthesis and dry-matter partitioning in fruiting and deblossomed dayneutral strawberry plants. J. Amer. Soc. Hort. Sci. 111:430-433.

Schechter, I., J.T.A. Proctor, and D.C. Elfing. 1994a. Apple fruit removal and limb girdling affect fruit and leaf characteristics. J. Amer. Soc. Hort. Sci. 119:157-162.

Schechter, I., J.T.A. Proctor, and D.C. Elfing. 1994b. Carbon exchange rate and accumulation in limbs of fruiting and nonfruiting apple trees. J. Amer. Soc. Hort. Sci. 119:150-156.

Scholes, J., N. Bunock, R. Wilde, and S. Rolfe. 1996. The impact of reduced vacuolar invertase activity on the photosynthetic and carbohydrate metabolism of tomato. Planta 200:265-272.

Scorza, R., L.G. May, B. Purnell, and B. Upchurch. 1991. Differences in number and area of mesocarp cells between small- and large-fruited peach cultivars. J. Amer. Soc. Hort. Sci. 116:861-864.

Siefker, J.H. and J.F. Hancock. 1986. Yield component interactions in cultivars of the highbush blueberry. J. Amer. Soc. Hort. Sci. 111:606608.

Stephenson, A.G. 1981. Flower and fruit abortion: Proximate causes and ultimate functions. Ann. Rev. Ecol. Syst. 12:253-279.

Stutte, G.W. and G.C. Martin. 1986. Effect of light intensity and carbohydrate reserves on flowering in olive. J. Amer. Soc. Hort. Sci. 111:27-31.

Swain, P.A.W. and R.L. Darnell. 2001. Differences in phenology and reserve carbohydrate concentrations between dormant and nondormant production systems in southern highbush blueberry. J. Amer. Soc. Hort. Sci. 126:386-393.

Taylor, B.K. and B. van den Ende. 1970. VI. Influence of autumn nitrogen applications on the accumulation of nitrogen, carbohydrate and macroelements in one-year-old-peach trees. Austral. J. Agr. Res. 21:693-698.

Terblanche, J.H., P.J.C. Stassen, I. Hesebeck, and D.K. Strydom. 1979. Effects of autumn nitrogen nutrition and a winter rest-breaking spray on the growth, development and chemical composition of young 'Golden Delicious' apple trees grown in sand culture. Sci. Hort. 10:37-48.

Weinberger, J.H. 1941. Studies on time of peach thinning from blossoming to maturity. Proc. Amer. Soc. Hort. Sci. 38:137-140.

Westwood, M.N., L.P. Batjer, and H.D. Billingsley. 1967. Cell size, cell number, and fruit density of apples as related to fruit size, position in cluster, and thinning method. Proc. Amer. Soc. Hort. Sci. 9:151-62. 